INDEPENDENT JOURNAL OF MANAGEMENT \& PRODUCTION (IJM\&P)

http://www.ijmp.jor.br

v. 12, n. 5, July-August 2021

ISSN: 2236-269X

DOI: 10.14807/ijmp.v12i5.1401

\title{
ASSESSING THE EFFECTS OF FLIPPED CLASSROOM AT THE TUNISIAN UNIVERSITY
}

\author{
Hanen Khanchel \\ Institute of Advanced Business Studies, University of Carthage, Tunisia \\ E-mail: Hanen.khanchel@gmail.com
}

Karim Ben Kahla

High Business School, Campus of Manouba, Tunisia

E-mail: Kbenkahla@gmail.com

Submission: $8 / 4 / 2020$

Revision: 8/19/2020

Accept: 8/26/2020

\section{ABSTRACT}

At the beginning of 2020, e-learning was not yet valued in the culture of Tunisian university. However, the COVID-19 Pandemic was the cause of the accelerated deployment of e-learning-related devices. Moreover, it seems that the context of health crisis experienced in the world and particularly in Tunisia represents a factor pushing Tunisian university to reduce, or even eliminate, face-to-face courses for precautionary measures. This is likely to allow students to improve their knowledge, especially for those who require great concentration and time for reflection. The paper shows a very different approach with an analysis of the students' difficulties by focusing on the mistakes made in solving the problems in the case study. The study makes an original contribution to knowledge. It breaks new intellectual ground. Indeed, flipped learning in particular seems to affect students on a psychological level, making them more engaged, more motivated, and better able to self-regulate. This is the intuition of many flipped learning instructors, but intuition is just a hypothesis. Nevertheless, the results indicate that there is a gap as regards the flipped classroom approach.

Keywords: COVID-19, flipped classroom; e-learning; cognitive overload; University 
ISSN: 2236-269X

DOI: 10.14807/ijmp.v12i5.1401

\section{INTRODUCTION}

Several published meta-analyses showed the advantages and disadvantages of the flipped classroom in comparison with a traditional approach in terms of student achievement (Naseri, 2019; Guerrero \& et al., 2015; Larsen, 2015; David \& et al., 2019; Cheng, Ritzhaupt, \& Antonenko, 2018; Hew \& Lo, 2018; Lo, Hew \& Chen, 2017; Love \& et al., 2014; Scott, Green \& Etheridge, 2016; Strayer, 2012, Bischop \& Verleger, 2013; Naccarato \& Karakok, 2015; Ziegelmeier \& Topaz, 2015; Giannakos, Krogstie \& Chrisochoides, 2014; O’Flaherty \& et al., 2015; Betihavas \& et al., 2016; Chua \& Lateef, 2014; Presti, 2016; Seery, 2015; Moore, Dickson-Deane \& Galyen, 2011). In the absence of convincing data, Akcayir and Akçayır (2018) advise in the state of "rather to make the class in the place than upside down".

However, Vincent Faillet (2018), also a researcher in education sciences, conducted a study in 2014 in science courses at a high school. His work reveals that students in the traditional classroom system are generally less efficient in the flipped classroom, while lowerlevel students in the traditional classroom perform better in the flipped classroom system (Abdelhaq \& Dawson, 2017).

Indeed, this inversion of the performance is to be compared with an adaptation of the students of good level to the traditional system and a tendency to work more for the pupils of lower level when they are in a system of flipped class. Such a penalization of "good students", although often observed, should not overshadow the benefits that are noted for students with low scores.

However, in an experimental study in 2015, American and Brazilian researchers relativize the impact of the flipped classroom. These researchers compared two groups that were taking a course in biology, the first in flipped class format, the second in a more traditional format. No difference in terms of results or motivation could be found between the two learning situations.

According to these academics, the benefits often attributed to the flipped classroom are actually the result of the active learning pedagogy that accompanies the flipped classroom (Lebrun \& et al., 2017). Hence, it is possible to do active pedagogy without resorting to the flipped classroom (Jensen, 2015).

The paper shows a very different approach with an analysis of the students' difficulties by focusing on the mistakes made in solving the problems in the cases studied. This work was conducted during the year 2019-2020 on two groups of students of the Tunisian university. 
INDEPENDENT JOURNAL OF MANAGEMENT \& PRODUCTION (IJM\&P)

http://www.ijmp.jor.br

v. 12, n. 5, July-August 2021

ISSN: $2236-269 X$

DOI: 10.14807/ijmp.v12i5.1401

In the following parts, we will discuss each of these findings in detail: In the first part, we discuss the theoretical foundations, devoted to the effects of the goal structure on cognitive load and learning. The second part performed an experimental evaluation. Finally, in a third part, we will discuss the consequences of the results obtained by the application of the flipped classroom on the design of learning situations.

\section{LITERATURE REVIEW}

In the flipped classroom, students receive courses in the form of online resources that they will be able to watch at home or elsewhere. In fact, we will mainly take advantage of the free time in class to organize activities, group projects and exchanges that will give a real meaning to the academic content (Baytiyeh, 2017). Hence, many alternatives are possible, but the goal is to move from a teacher-centered model to a student-centered model to meet individual needs (Lebrun \& et al., 2017).

It is therefore more of a philosophy than a method properly speaking. Hence, it is a way to approach teaching, to rethink what is done in class to improve the learning experience (Zhou, Shutao \& Zhang, 2017).

This model provides many advantages, but the main thing is the freedom it provides. Teachers are liberating for the students because they are no longer forced to sit in silence for hours, they can now "live" in class and have rich exchanges with the teacher and other students.

This model is also liberating for the teacher, who is no longer obliged to repeat the same lessons over again to sleepy or restless classes, and who finally has time to discuss directly with one another or in small groups with his students. He takes on a role of tutor, by their side and always available, which allows him to understand them. He can tailor his help to everyone and his work becomes more effective. As a result, relationships are more relaxed and academic results are improved (Syeda, 2017).

From a practical point of view, this operation is once again more logical: a student who blocks on a problem is no longer forced to give up on his own. This work will now be done in class, which can take on the appearance of a workshop (Sahin, \& Kurban, 2016). On the other hand, when a student watches his lessons in videos, he can pause at any time and review a course as many times, as he wants to make sure he understands it.

He can also take the opportunity to write down questions that he will then ask the teacher in class. Conversely, in the classical model, few students dare to interrupt a course and admit that they did not understand something; they spend the rest of the hour lost because they 
INDEPENDENT JOURNAL OF MANAGEMENT \& PRODUCTION (IJM\&P)

http://www.ijmp.jor.br

v. 12, n. 5, July-August 2021

ISSN: $2236-269 X$

DOI: 10.14807/ijmp.v12i5.1401

lack an element, and when at the end of the course, the teacher often has no time to answer questions (Lebrun \& et al., 2017).

The development of information and communication technologies (ICT) makes it possible to set up resources in more varied forms (Engel, Heinz \& Sonntag, 2017). The first advantage of these digital devices is their "fun" side, the diversity of formats, the multiple possibilities of consultation (Kibuku, Ochueng \& Wausi, 2020). As long as the content is on an e-learning platform, the monitoring of student work will be facilitated by the possibility of knowing who performed the required tasks (Chevalier \& al., 2014).

In fact, the Moodle platform is a web-based open source e-learning that offers to a community of teachers and learners many possibilities to interact (www.moodle.org). This platform was designed to promote a socio- constructivist approach, but it is also adopted to more traditional teaching styles, as a complement to classroom education. It is widely used in higher education by many universities, colleges and high schools (Karkar, Fatlawi \& AlJobouri, 2020).

However, the Moodle platform is seen as an action-oriented approach where the role of the trainer is to create a learning environment that enables learners to build their knowledge from their own experiences (Korableva and et al., 2019). This approach differs from the usual practice of the teacher who transmits knowledge and assesses what the student must master.

Similarly, Benjamin Bloom developed in his 1956 book, the Higher-order thinking skills (HOTS). Furthermore, Anderson and Krathwohl (2001) revised the cognitive process labeled from the noun forms to verb forms. The revised one encompasses some cognitive performances namely remembering, understanding, applying, analyzing, evaluating, and creating. In addition, the top skill in the taxonomy is revised as well where the creating process is placed number one on the taxonomy.

For these reasons, the concept of flipped classroom deserves our attention. Our old model was justified when we had no other way to transmit the knowledge, but now that technologies allow it, it is no longer necessary. It is time to step back and rethink education (Lezer, Shabatura \& Karnaukhov, 2020). Technologies have become ubiquitous, so let us be pragmatic: rather than banning them in class, using their potential and giving our students the urge to learn online (Radcliffe and et al., 2016).

Indeed, e-learning is gaining momentum in the context of health crisis. New technologies are changing the way teaching is done and the pressure is growing for Tunisian 
DOI: 10.14807/ijmp.v12i5.1401

university, who have to integrate digital platforms in order to share knowledge. Therefore, the management module is taught by using Moodle platform to undergraduate students in all courses of our university.

Hence, there are many opportunities to be grabbed, but many challenges also exist in elearning (Sit \& Guo, 2019). It is indeed feared to see some of students lack motivation in the face of difficulties, which could lead from the beginning of the module, a lack of concentration in the subject, and this, especially since many will have never to mobilize the developed knowledge (Kite \& et al., 2020).

\section{RESEARCH QUESTIONS AND HYPOTHESES}

The study shows a very different approach with an analysis of the students' difficulties. By focusing on the mistakes made in solving the problems in the case study as an exercise developed by the students, we wanted to answer the following questions:

- Are students' errors in an exercise-solving approach that incorporates the flipped classroom system as a pre-learning step identical to those students who have an active learning pedagogy?

- Does the flipped classroom system make it possible to reduce the number of errors in the resolution of an exercise?

In order to answer our two research questions, we have formulated the following null hypotheses:

- Hypothesis H1: Students in the flipped classroom make fewer errors than those in the traditional classroom.

- Hypothesis H2: The scores obtained by the students who use the flipped classroom system to produce the result are the same as those of the students who directly elaborate the result with the traditional pedagogical approach.

\section{METHOD}

In what follows, we first present the pedagogical approach, and then we describe the learning process followed. We then process the flipped classroom and present the digital tools used in this paper.

\subsection{Pedagogical approach}


DOI: 10.14807/ijmp.v12i5.1401

In this paper, we limit ourselves to the first level of learning, that of the principles of management that is reflected in the definition of key concepts. In order to help non-specialist students assimilate the course, we considered a four-step approach as advocated by Kolb (1984) (Figure 1).

Indeed, there are four modes of adaptation facing the cognitive overload (Goedhart and et al., 2019). They are anchored in the cognitive functions of perceiving, thinking, acting and feeling (Sweller, 1988). The four modes form two axes on which the Kolbian learning cycle is based. The cycle of learning proposed by Kolb (1984) is composed of four phases: Concrete Experience, Reflective Observation, Abstract Conceptualization and Hypothesis (Active Experimentation).

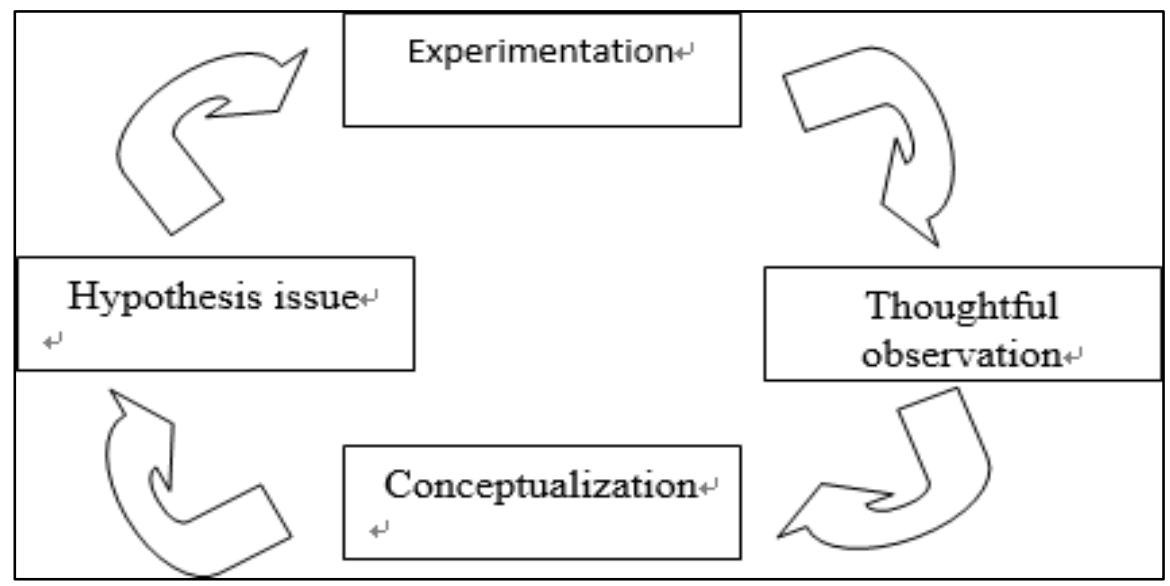

Figure 1: Generic Process of learning (Kolb, 1984)

To help students perform their level, we propose the "flipped classroom system". Lebrun (2017) introduces the hypothesis that the concept itself covers a large possibility of actual practices. This is to show how what he calls Type 1 (original type of the flipped class: "lessons at home, homework in class") has changed according to the practices, disciplines or even the pedagogical culture teachers.

He therefore proposes to extend the concept of the flipped class to several types of flipped classes by giving space to contextualization through the autonomous exploration of content. Following their explorations, learners return to class by presenting and sharing the results of their research. After a confrontation in debate mode, they generalize, later, through a phase of abstract conceptualization and in class, they contextualize again by the transfer of knowledge.

In their book, Lebrun et al. (2017) associate this scenario of activities in hybrid mode with experiential learning (see the Kolb cycle). In his subsequent research, Lebrun et al. (2017) 
DOI: 10.14807/ijmp.v12i5.1401

validates this hypothesis by highlighting several types of flipped class and demonstrating the differentiated effects of these types on different factors of learning.

\subsection{Learning process}

In the following subsections, we will cover each of these steps in detail (Figure 1):

- Concrete Experience is the moment when the student performs a task. The activity must be authentic to real-world tasks. During this experience, the student must use knowledge possessed and know-how to engage in the virtual activity.

- Reflective Observation leads the student to reflect on the experience he has experienced. He must step back and report how he experienced the case study: attitude, aptitude. The teacher can guide the student or offer him tools to help him in his approach (Chevrier, 2000).

- Abstract Conceptualization allows the student to construct general concepts, based on previous experience, which should be applied to different situations.

During the last stage, that of the issue of hypotheses (Active Experimentation), the student will have to deduce hypotheses that can be confirmed in a new concrete experience.

At the end of the cycle, the student experienced a conscious process involving reorganization or a change of ideas in the light of new awareness. These are manifested as significant changes in the individual's level of knowledge, skills, values, attitudes, habits, and possibly self-image (Barkley \& Major, 2020).

However, the instructional designer should select or create learning activities and write teachers' guides. Hence, learners can live through the four stages of Kolb's learning cycle:

- An experience that takes into account the particularities expressed below.

- A document allowing the teacher to guide the student during the reflective observation. This document can take the form of a corrected document supporting the teacher when he directs the students towards the discovery of the correct answers, correct sequences to use (Tofade et al., 2013).

- A document clearly indicating the concepts to be drawn from the lived experience to which the teacher must refer during the conceptualization phase.

- A new experience to give life to students that will enable them to validate, by experimenting, the new concepts they have just acquired. Therefore, the selection of 
DOI: 10.14807/ijmp.v12i5.1401

this strategy implies that teachers are comfortable with the phases of thoughtful observation and conceptualization (Rogers \& Révész, 2020). Indeed, teachers have an important role with students, because it is "an opportunity for feedback by sharing perceptions about the individual's ways of being or acting in order to help him or her to walk" (Zhoy \& Zhang, 2017).

\subsection{Digital tools}

The digital tool, democratized and accessible, is a facilitator of flipped class pedagogy. Therefore, Taurisson (2015) proposes 3 stages of the activity that combined flipped class pedagogy as following:

- The flipped class only (requires online courses, can possibly come from the teacher himself and incorporating capsules videos, slideshows, forum, and simulations).

- Project pedagogy only (needs to create a real situation triggering).

- Individual progression (requires online courses, planning of learning cycle and a monitoring and scoring system).

In all these phases, the digital tool is a support for diversifying practices and productions, facilitating exchanges, differentiating and regulating learning of each student. Students then become producers; they can share and propose resources, and add and sort information.

The benefits of using digital tools in learning are important in development of communication, cooperation, reflection, creativity to make the great motivation to learn, the best information retention, and the best comprehension (Tractenberg et al., 2020). This concept can be used in any pedagogical configuration, but a flipped class will have much more time to devote to projects than a traditional classroom (Taurisson \& Herviou, 2015). We can in this perspective refer to Dufour (2014, p. 44) who notes that, "the flipped class is an original model that allows, from concepts pedagogical tools, to facilitate student learning. It is also a relevant way of using new technologies for pedagogy ".

The Moodle platform allows learners to interact with their learning resources when they are far away from their place of learning environments (www.moodle.org). However, Mercant (2016) proposes that this platform integrate tools and learning activities that are geared towards 4 elements below:

- Synchronous communications (visible online people, chat), 
DOI: 10.14807/ijmp.v12i5.1401

- Asynchronous communications (forum),

- Collaborative learning,

- Critical reflection (poll, vote, feedback, expectations).

We take the reference of the digitization of resources according to Lebrun et al. (2016) who considers that the flipped classes could be a good arrangement of different training techniques and different pedagogical currents.

Similarly, the Moodle platform allows teachers to put course elements the session, activities are offered to students with applications and resources that allow them to analyze, simulate, observe and use numerical models. Similarly, he considers Moodle platform as a teaching tool for students of colleges and high schools because the use is open to teachers and students from a digital workspace (www.moodle.org).

Moodle is a tool for new class-oriented practices (Mercant, 2016). It offers some advantages:

- It allows student to read the documents at his or her own pace.

- It allows each student to take time to think.

- It provides differentiated aids.

This platform benefit from many features developed as pedagogical tools to communicate and interact. The teacher can use these features to create courses such as information, resources and content in different formats (recordings, documents, videos, presentations, connections). Then, he opens the access to these courses to the students he chooses according to the educational objectives and difficulties encountered by students (Puzanova \& Larina, 2019).

Students' access courses, carry out the work proposed by the professor, exploit the resources, answer quizzes, questionnaires, and return to the teacher documents, records, and works (Mercant, 2016). The Moodle platform offers the possibility to ask students about online tests, deposits of homework, forums, chats, questionnaires, wikis, exchanges and collaborative works (www.moodle.org). All members of the community access the route via an identifier and a password, from any point of access to the Internet, and this, what whatever the interface (workstation, tablet, and mobile phone). 
INDEPENDENT JOURNAL OF MANAGEMENT \& PRODUCTION (IJM\&P)

http://www.ijmp.jor.br

v. 12, n. 5, July-August 2021

ISSN: $2236-269 X$

DOI: $10.14807 /$ ijmp.v12i5.1401

According to Mercant (2016) the contributions of digital platforms can facilitate learning when pedagogy is active and there is a link between tools, methods and objectives. The role of the teacher is in the triptych works «Information - Activities - Productions ". Therefore, this complementarity allows each student to meet the objectives at his own pace.

Similarly, Bergmann and Sams (2014) find that flipped pedagogy speaks the same language as students of today with the use of digital resources and social media as Facebook, YouTube, Twitter, Snapchat, MySpace, etc. These resources allow students to connect to the digital world permanently (West, 2019).

The flipped class allows students to have more time to manage their own learning and produce knowledge in a more autonomous way. In a flipped class, students are responsible for their learning. It is rather advised to draw inspiration from it and to adapt it to its subject, to its teaching style, and to profile of his students to practice the approach that does not spill that class but also postures and mentalities (Dumont \& Berthiaume, 2016).

According to Taurisson and Herviou (2015), digital platform will be more helpful. It is not fundamental, because the central notion is the active learning pedagogy. A digital tool is a new teaching subject that helps to perform tasks of learning.

\section{RESULTS}

The subsequent section presents the results from a thematic analysis of these experiments over a period of COVID-19. The findings section are divided into two subsections:

- The first subsection is devoted to errors analysis of students from both groups.

- The second subsection is devoted to scores analysis of students from both groups.

\subsection{Error analysis}

We observed whether each result produced by the students corresponded to a given textual specification. Similarly, we counted the number of times each error was repeated with the same result and then we calculated their frequency. However, it should be noted that we did not detect errors committed into results developed by students in the AC group.

Thus, the errors were made during the experimental step. For this reason, we limit ourselves to describing the errors made by the students when solving the problem. After analyzing the diagrams, we found a total of 142 errors in the AC group and 276 errors in the SC group. Therefore, the AC group has a lower percentage of errors than the SC group. 
DOI: 10.14807/ijmp.v12i5.1401

They account for $57.74 \%$ of the total number of errors committed by the AC group and $24.64 \%$ for the SC group. Note also that the majority of errors (37.32\% for the AC group and $21.74 \%$ for the SC group). This type of error is probably due to a misunderstanding of the case study problem.

We also noticed that in the AC group, 8.82\% of the errors are of type errors at the level of cause analysis against $20.29 \%$ for the group SC. This lower percentage of errors for the AC group can be explained by the adoption of the approach before developing the result. However, this approach may have allowed the students of the AC group to reflect on the information characterizing each step of the experimentation and on the identifier of each of them, as well as their understanding of the specifications of the problem to be solved before moving on to a more complex representation.

In order to verify if there is a statistically significant difference between the percentages of the most frequent errors committed by the two groups, we used a comparison test of proportions for the errors or the test of the reduced difference.

Note that the errors E1, E2, E3, E4, E7, E9, E11 and E12 have not been taken into consideration because of their low frequency.

The results of the reduced gap tests obtained are confirmed. Recall that the total number of errors is 142 for the AC group and 276 for the SC group. However, it should be noted that the data collected from the initial exam showed that $100 \%$ of participants of both groups had a similar school education, never repetition licensed and have no prior knowledge of management, nor in terms of pedagogy adopted.

Indeed, it appears that the absolute value of the reduced deviation is greater than 1.96 for the errors E5, E8, E10, E13 and E14. The difference between the percentages of errors is therefore statistically significant, which leads us to reject the null hypothesis. We can therefore say that the group SC has a higher percentage for the error E5, E8 and E10 than the group AC. Thus, the approach allowed students to commit these types of errors.

For error E6, the absolute value of the reduced deviation is less than 1.96. The difference between the percentages is therefore not significant. We cannot reject the null hypothesis. The difference observed between the percentages may or may not have as its origin the randomness of the sampling. Moreover, the AC group has a higher percentage of errors related to problem solving (E13 and E14). Students in the SC group may have had more time to think about the case studied because they did not have to build knowledge and it did not address this issue. 
DOI: 10.14807/ijmp.v12i5.1401

In order to see if the adoption of the approach during the learning process can be effective in case resolution and to produce correct results, we have established a reduced gap test.

In total, the AC group was able to solve $90 \%$ of the exercises whereas the SC group could only do $67.14 \%$. The reduced gap test shows a significant difference between the two groups for the case resolution frequency. Indeed, the absolute value of the reduced difference for the hypothesis (H1) is 4.28 . The result is significant to $\mathrm{p}<0.05$; the null hypothesis $\mathrm{H} 1$ is therefore rejected. Thus, the successful resolution of the case is related to the active learning pedagogy adopted. In addition, the flipped classroom system constitutes a benefit for students.

The analysis also shows that the absolute value of the reduced deviation for the hypothesis (H2) is 0.91 at the $5 \%$ threshold. The AC group students have certainly solved the exercise better than the students in the SC group, but this does not imply that they produce correct results. This can be explained by the fact that, in the flipped class, the rules are not explained (See table 1).

Hence, this approach to learning has been the height level of motivation and enjoyment for participants. The active participation of all group has been amazing. The instructional task was set by the teacher which was aligned with the curriculum and learning outcomes on the programme.

Table 1: Distribution of errors

\begin{tabular}{|c|c|c|c|c|}
\hline Errors category & \multicolumn{2}{|c|}{ AC Group } & \multicolumn{2}{|c|}{ SC Group } \\
\hline $\begin{array}{l}\text { Category } 1 \text { : Errors in problem } \\
\text { identification }\end{array}$ & $\mathrm{N}$ & F (\%) & $\mathrm{N}$ & F (\%) \\
\hline Description & & & & \\
\hline $\begin{array}{l}\text { A poorly defined } \\
\text { problem }\end{array}$ & 1 & $0,70 \%$ & 4 & $1,45 \%$ \\
\hline $\begin{array}{l}\text { A problem whose } \\
\text { nuances don't } \\
\text { completely } \\
\text { understand }\end{array}$ & 0 & $0 \%$ & 0 & $0 \%$ \\
\hline $\begin{array}{l}\text { Information is } \\
\text { missing }\end{array}$ & 0 & $0 \%$ & 0 & $0 \%$ \\
\hline Total 1 & 1 & $0,70 \%$ & 4 & $1,45 \%$ \\
\hline $\begin{array}{l}\text { Category } 2 \text { : Errors in the choice } \\
\text { of the method }\end{array}$ & $\mathrm{N}$ & F (\%) & $\mathrm{N}$ & F (\%) \\
\hline Description & & & & \\
\hline Inappropriate & 0 & $0 \%$ & 0 & $0 \%$ \\
\hline
\end{tabular}


INDEPENDENT JOURNAL OF MANAGEMENT \& PRODUCTION (IJM\&P)

http://www.ijmp.jor.br

v. 12, n. 5, July-August 2021

ISSN: 2236-269X

DOI: 10.14807/ijmp.v12i5.1401

\begin{tabular}{|c|c|c|c|c|c|}
\hline E5 & False & 18 & $12,68 \%$ & 60 & $21,74 \%$ \\
\hline E6 & Lack & 22 & $15,49 \%$ & 44 & $15,94 \%$ \\
\hline E7 & Off topic & 0 & $0 \%$ & 0 & $0 \%$ \\
\hline E8 & Poorly & 6 & $4,23 \%$ & 38 & $13,77 \%$ \\
\hline \multirow[t]{2}{*}{ E9 } & Not applicable & 1 & $0,70 \%$ & 6 & $2,17 \%$ \\
\hline & Total 2 & 47 & $32,47 \%$ & 148 & $53,62 \%$ \\
\hline \multicolumn{2}{|c|}{$\begin{array}{c}\text { Category } 3 \text { : Errors in causes } \\
\text { analysis }\end{array}$} & \multirow[t]{2}{*}{$\mathrm{N}$} & \multirow[t]{2}{*}{$\mathrm{F}(\%)$} & \multirow[t]{2}{*}{$\mathrm{N}$} & \multirow[t]{2}{*}{ F (\%) } \\
\hline Code & Description & & & & \\
\hline E10 & $\begin{array}{l}\text { Omission leading to } \\
\text { an undesirable } \\
\text { outcome }\end{array}$ & 11 & $7,75 \%$ & 46 & $16,67 \%$ \\
\hline E11 & Error data collection & 1 & $0,70 \%$ & 10 & $3,62 \%$ \\
\hline \multirow[t]{2}{*}{ E12 } & Incident reporting & 0 & $0 \%$ & 0 & $0 \%$ \\
\hline & Total 3 & 12 & $8,82 \%$ & 56 & $20,29 \%$ \\
\hline \multicolumn{2}{|c|}{$\begin{array}{c}\text { Category } 4 \text { : Errors in problems } \\
\text { solving }\end{array}$} & \multirow[t]{2}{*}{$\mathrm{N}$} & \multirow[t]{2}{*}{$\mathrm{F}(\%)$} & \multirow[t]{2}{*}{$\mathrm{N}$} & \multirow[t]{2}{*}{ F (\%) } \\
\hline Code & Description & & & & \\
\hline E13 & $\begin{array}{l}\text { Team-working } \\
\text { errors }\end{array}$ & 53 & $37,32 \%$ & 60 & $21,74 \%$ \\
\hline E14 & $\begin{array}{l}\text { Poor execution of a } \\
\text { task }\end{array}$ & 29 & $20,42 \%$ & 8 & $2,90 \%$ \\
\hline & Total 4 & 82 & $57,74 \%$ & 68 & $24,64 \%$ \\
\hline & Total & 142 & $100,01 \%$ & 276 & $100 \%$ \\
\hline
\end{tabular}

\subsection{Scores analysis}

Firstly, we compared the results of the summative evaluation of the work group with those of the experimental group. Then, we determined whether the level of understanding of the first group was greater than that of the second group. Finally, we determined whether group could proceed to the next step in learning.

Table 2: Results of Experimental group (AC) and Works group (SC) subjects

\begin{tabular}{ccccccc}
\hline Learning system & 1 & 2 & $\begin{array}{c}\text { Statistical } \\
\text { standard } \\
\text { deviation }\end{array}$ & $\begin{array}{c}\text { Standard } \\
\text { errator }\end{array}$ & \multicolumn{2}{c}{$\begin{array}{c}\text { 95\% confidence } \\
\text { interval for the } \\
\text { average } \\
\text { Min }\end{array}$} \\
\hline $\begin{array}{c}\text { Flipped } \\
\text { classroom }\end{array}$ & 220 & 4.69 & 1.16 & 0.24 & 4.17 & 5.21 \\
\hline $\begin{array}{c}\text { Traditional } \\
\text { classroom } \\
\text { system }\end{array}$ & 280 & 3.87 & 1.27 & 0.24 & 3.38 & 4.46 \\
\hline
\end{tabular}

The average for the AC group is 4.69, while it is 3.87 for the SC group. The standard deviation of the AC group (1.16) is slightly lower than that of the SC group (1.27). The average 
ISSN: 2236-269X

DOI: 10.14807/ijmp.v12i5.1401

is therefore higher for the active learning pedagogy with flipped class than for the traditional approach.

This suggests that the flipped classroom system has a positive effect on the result. To determine if there is a significant difference, we performed a one-way analysis of ANOVA variance, the results of which are shown in Table 3.

Table 3: ANOVA variance analysis results

\begin{tabular}{cccccc}
\hline $\begin{array}{c}\text { Source of } \\
\text { variation }\end{array}$ & $\begin{array}{c}\text { Sum of the } \\
\text { squares of } \\
\text { the gaps }\end{array}$ & $\mathrm{dl}$ & $\begin{array}{c}\text { Average of } \\
\text { squares }\end{array}$ & F. test & P (Sig.) \\
\hline inter groups & 8.247 & 1 & 8.2473 & 5.456 & 0.02 \\
\hline intra groups & 72.554 & 48 & 1.511 & & \\
\hline Total & 80.801 & 49 & & & \\
\hline
\end{tabular}

The calculated F value (5.456) is greater than F critical (0.98) with a p value of 0.02 , lower than the estimated error margin of 0.05. This leads us to reject the null hypothesis and to consider that there is a significant difference between the performances of students from the both groups, in favor of the first group. These results show that three-quarters of students find the active learning pedagogy to be motivating and believe that it has allowed them to organize their ideas, to develop their faculties of abstraction analysis and to improve their scores (See Figure 2 ).

$72 \%$ of the students think that it helped them to the result and facilitated their learning management versus $28 \%$ who disagree $(14 \%)$ or even disagree fully (14\%). A similar percentage of students (73\%) said that the active learning pedagogy allowed them to better understand the problem solving specifications of the case study in management. The transition from the active learning pedagogy to the result was simple for $82 \%$ of the students surveyed and fast for $64 \%$ of them. However, half of the students think that this approach makes them waste time and resources and prefer to solve the exercise directly in class without going at home.

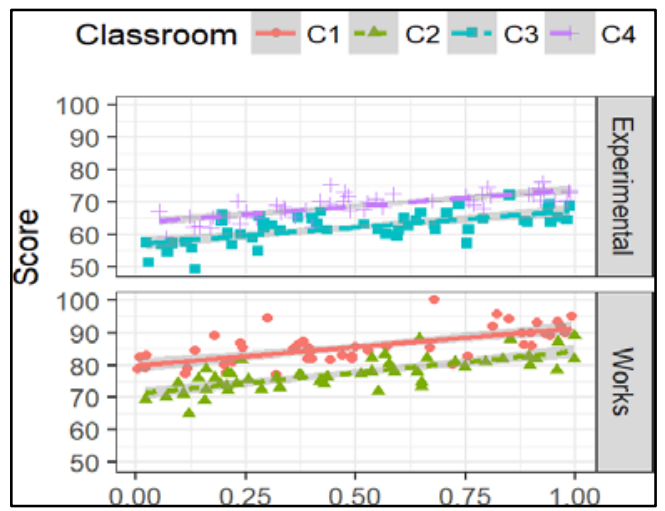


Figure 2: Plot of the scores

\section{DISCUSSION}

In seeking to better understand the advantages of the flipped classroom method as a means of facilitating e-learning, we found that the active learning pedagogy adopted in the Tunisian university was able to overcome the health crisis experienced by students in the work group in order to reduce, or even eliminate, face-to-face courses. In some cases, they have made mistakes. In other cases, they have forgotten to specify the causes of the problem and have sometimes tended to omit associations mentioned in the specifications.

Indeed, the results have shown the existence of three main factors of the errors that affect the performance of the students in the resolution of exercises, the person, the method and the problem to solve. Errors due to the unfamiliarity of the application domain and the complexity of the problem to be solved imply significant cognitive activity to perceive the essential concepts and interactions necessary for carrying out the various tasks.

As a result, errors increase as the complexity of the case to study increases. Hence, the more familiar the fields of application, the more likely students are to understand the specifications and produce a result that better meets these specifications (Fry, 2003). This is why we chose, on the one hand, at the beginning of the teaching, a simple and familiar field of application, and on the other hand, diversified the examples, the exercises and the level of difficulty for both groups. In doing so, we wanted to increase students' motivation, make their understanding more progressive and easier, and thus reduce their cognitive load (Sweller, 1988).

Students in the work group seem to have encountered some additional difficulties when they sought to understand the specifications of the case to study, and at the same time to design one. The problem of understanding the management course, in flipped class, requires indeed a cognitive effort of participants. In this regard, the results showed that it would have been possible to avoid some of the errors listed earlier, if the understanding phase of the key concepts had been separated from the problem solving phase.

Students would then have been able to produce a more informal description of the content of the extradite information of the case studied by first producing a result in flipped class to solve the problem. Thus, we also consider that the integration of the active learning pedagogy in the Tunisian university makes it possible to represent the information of the field in visual form, being able to be easily interpreted. Indeed, in such context of health crisis, 
DOI: 10.14807/ijmp.v12i5.1401

students are first led to think actively about the goal specifications in order to understand subject and then to check the solution obtained twice, once after the resolution of problems and a second time to the final result. Therefore, students use the following arguments:

- The subjects can proceed by successive hypotheses on the structure of the goal, in particular on the next sub-goal. If the result is as expected, then just continue; if the result does not conform to what was expected, then we change;

- There is not learning when using a means-ends analysis in problem solving transformation;

- The goal is not clearly specified by the subject in a problem-solving situation, hence the lack of medium- end analysis in this type of situation;

- The specification of the goal induces a means-ends analysis, which can hinder the learning of the structure, the rule, increase the resolution time as well as the number of missteps.

Nevertheless, we consider that this approach is motivating and that it allows students a better understanding of the work, a better organization of the ideas, a reduction of the cognitive load and better results (Almulla, 2019). Therefore, the idea of the group is to pose questions of enquiry and quizzes, based on the knowledge of the problem. After discussion and collaboration within the group whereby all students had something to say-either by reconstructing the meaning, identifying unknown terminology and clarifying any areas of misunderstanding or by raising questions that needed further investigation, meant full participation of the subject.

Indeed, students may be called in the courses to play the role of participants. Thus, learners will be able, by their summary knowledge, to improve their knowledge. Then, teachers drew the attention of them to the fact that it is not excluded that they conceive, personally, improvement interventions in group discussions, meetings, projects, and presentations. Therefore, it is important to make students understand the relevance of the management course and lead them to make the necessary efforts to learn by using Moodle platform.

Note, however, that the adoption of the active learning pedagogy in the Tunisian university is not "easy" and requires additional effort and time (Salisbury, Hannon \& Peasley, 2019). Hence, it is recommended to strive for a course organization that is clear, methodical, and intuitive (Griffioen, Groen \& Nak, 2019). 
INDEPENDENT JOURNAL OF MANAGEMENT \& PRODUCTION (IJM\&P)

http://www.ijmp.jor.br

v. 12, n. 5, July-August 2021

ISSN: $2236-269 X$

DOI: 10.14807/ijmp.v12i5.1401

Help learners move through content and tasks smoothly and seamlessly, so that their attention remains focused on learning the material. If they have to click out of a module and into another folder to watch a required video, that can be distracting or frustrating if it's hard to find. Similarly, requiring learners to exit from a sequence of content pages and access a quiz by navigating to a different location wastes time and mental energy. Instead, try to order materials and tasks such that the flow makes sense for someone new to the course. Ask an online-savvy colleague for help if teacher are too close to the content and unable to see it from a newcomer's perspective.

\section{CONCLUSION}

The review of the literature indicates that there is an increased contribution to the educational research by the use of flipped classroom. The results are pertinent to instructors, teachers and learners because they highlight the importance of the use of an active learning pedagogy to achieve predetermined goals and transfer of knowledge.

Firstly, e-learning applications can be provided by the use of moodle platform. Similarly, students are stimulated to move out of the classroom to learn anywhere and anytime (Shaik, Makhecha \& Gouda, 2020). Moreover, it is found that teachers who used the flipped classroom model improved the sort of key resources they have, experienced reflective group discussions online and shared their practices among each other.

Reflective practices were integrated with case study, and were linked with evaluation requirements. Learners' perceptions of reflective group discussions were obtained via exams and reflective essays. The key benefits of reflective forum discussions perceived by learners included peer learning, peer and tutor support and multi-perspective critical thinking.

Learners welcomed the inclusion of reflective group discussions online into their curriculum, not as a substitute of, but rather, complementary to reflective writing online. Learners invoked that reflective writing and reflective forum discussions were beneficial in different ways. The supportive, multiperspective nature and interactive of reflective group discussions online was appealing to learners.

It was found that the flipped classroom approach has been widespread in various courses with the aim of increasing interaction online and personalized contact between students and teachers in the classroom. Out-of-class activities have been interchanged online for a limited period of courses. The majority of interviews show that there was a positive change in student views towards the flipped classroom approach (Poleman, Jenks-Jay \& Byrne, 2019). 
INDEPENDENT JOURNAL OF MANAGEMENT \& PRODUCTION (IJM\&P)

http://www.ijmp.jor.br

v. 12, n. 5, July-August 2021

ISSN: $2236-269 X$

DOI: 10.14807/ijmp.v12i5.1401

Then, we see instructors' reflections on the nature of the COVID-19 context of the elearning start becoming a much more central interest to ensure course continuity in the Tunisian university. They discuss at length the health crisis that characterize today's learning context and which pose a particular problems to students in face-to-face courses as well as to those who design teaching interventions.

Concern for technology as a primary driver to the Tunisian university a factor continuing to learn during this period. This finding stands in contrast to the active pedagogy approach by some other instructors in the observation of cognitive overload at the outset of their interviews. They add that the context has changed but who choose not to reflect on the digital transformations themselves in detail. These differences of approach may be a matter of digital devices used; they may also reflect different views regarding the importance of an explicit assessment of the digital transformations that occurred during the COVID-19 period.

Furthermore, we see that the gap became more important between two groups of students' difficulties by focusing on the mistakes made in solving the problems in the case study. Students around whom the majority of the questions were framed in the exam continue to be at the center of instructors' concerns as well. Teachers are ready to facilitate learning for two groups that were taking a course in management, the first in flipped class format, the second in a more traditional format.

Finally, the findings revealed more success and student motivation from flipped classroom compared to traditional classroom in teaching management to undergraduate students. It seems that application of new teaching methods could be effectively introduced to improve levels of education and student learning (Lebrun et al., 2017).

\section{LIMITATION AND RECOMMENDATIONS FOR FUTURE RESEARCH}

The research investigates only undergraduate students of the Tunisian university, specifically those registered in the second semester of 2019-2020. Consequently, the results cannot be generalized beyond the study population and similar context in such health crisis experienced in Tunisia.

Further investigation is suggested to identify design specifications of flipped classrooms and to intensively research the use of ICT and other assessment instruments.

Furthermore, it is recommended to conduct research on the effect of a flipped learning environment on obtaining learning outcomes and an optimal amount of face-to-face instruction that provides e-learning benefit for students from flipped teaching. 
DOI: 10.14807/ijmp.v12i5.1401

\section{REFERENCES}

Abdelhak, A., Asmaa, E., Abdelfatteh, H., \& Aziz, D. (2017). Improving the Teaching of ICT Engineering using Flipped Learning: a personalized model and a case study, Production, DOI: 10.1590/0103-6513.227416

Abeysekera, L., \& Dawson, P. (2015). Motivation and cognitive load in the flipped classroom: Definition, rationale and a call for research. Higher Education Research and Development, 34(1), 1-14. DOI: 10.1080/07294360.2014.934336

Almulla M. (2019). The Efficacy of Employing Problem Based Learning (PBL) Approach as a Method of Facilitating Students' Achievement. IEEE Access PP, (99),1-1, DOI: 10.1109/ACCESS.2019.2945811

Anderson, L., \& Krathwohl, D. (2001). A taxonomy for learning, teaching, and assessing. New York: Longman.

Barkley, E. F., \& Major, C. H. (2020). Student engagement techniques: A handbook for college faculty: John Wiley \& Sons.

Hoda Baytiyeh. (2017). The flipped classroom model: when technology enhances professional skills, International Journal of Information and Learning Technology, DOI: 10.1108/IJILT-07-2016-0025

Betihavas, V., Bridgman, H., Kornhaber, R., \& Cross, M. (2016). The evidence for 'flipping out': A systematic review of the flipped classroom in nursing education. Nurse Education Today, 38, 15-21. DOI:10.1016/j.nedt.2015.12.010

Bergmann, J., \& Sams, A. (2012). Flip Your Classroom: Reach Every Student in EveryClass Every Day. ISBN 978-1564843159.

Bishop, J. L., \& Verleger, M. A. (2013). The flipped classroom: A survey of the research. In 120th ASEE national conference and exposition, Atlanta, GA (paper ID 6219).

Washington, DC: American Society for Engineering Education.

Bloom, B. S. (1956). Taxonomy of educational objectives, handbook I: The cognitive domain. New York: David McKay.

Chua, J. S. M., \& Lateef, F. (2014). The flipped classroom: Viewpoints in Asian universities. Education in Medicine Journal, 6(4), 20-26. DOI:10.5959/eimj.v6i4.316

Cheng, L. A. D. \& Ritzhaupt, P. A. (2018). Effects of the flipped classroom instructional strategy on students' learning outcomes: A meta-analysis, Educational Technology Research \& Development, 1-32, https://doi.org/10.1007/s11423-018-9633-7

David, C.D., Van Alten, C. P., Jeroen J. L. K. (2019). Effects of flipping the classroom on learning outcomes and satisfaction: A meta-analysis, Educational Research Review, https://doi.org/10.1016/j.edurev.2019.05.003

Dove, A., Blanks, B., Dunleavy, M., \& Bennett, T. (2019). Exploring online professional development for enhancing elementary teachers' mathematical skills and instructional effectiveness. In K. Graziano (Ed.), Proceedings of Society for Information Technology \& Teacher Education International Conference (pp. 2148-2151). Las Vegas, NV, United States: Association for the Advancement of Computing in Education (AACE). Retrieved April 5, 2020 from https:/www.learntechlib.org/primary/p/207944/. 
Dufour, H. (2014). The flipped classroom. La classe inversée. Technologie, 193, 44-47. https://www.ac-paris.fr/portail/upload/docs/application/pdf/201410/articletechnologie193_classe_inversee_hdufour_bd.pdf

Dumont, A., \& Berthiaume, D. (2016). Reverse pedagogy: Teaching differently in higher education with the reverse class. [La pédagogie inversée : Enseigner autrement dans le supérieur avec la classe inversée]. 1ère éd. p 1-47.

https://biblio.helmo.be/opac_css/doc_num.php?explnum_id=4010

Fry, H., Ketteridge, S., \& Marshall, S. (2003). Understanding student learning, A handbook of teaching and learning in higher education: enhancing academic practice (925). Londres : Kogan Page.

Faillet, V. (2018). The metamorphosis of the school when the students make the class. [La métamorphose de l'école quand les élèves font la classe], Descartes et Cie.

Goedhart, N. S. et al. (2019). The flipped classroom: supporting a diverse group of students in their learning. Learning Environ Res., 22, 297-310. https://doi.org/10.1007/s10984-01909281-2

Giannakos, M. N., Krogstie, J., \& Chrisochoides, N. (2014). Reviewing the flipped classroom research: Reflections for computer science education. In Proceedings of the computer science education research conference (23-29). ACM.

Gokce, A., \& Murat, A. (2018). The flipped classroom: A review of its advantages and challenges, Computers \& Education 126. August 2018, DOI: 10.1016/j.compedu.2018.07.021

Griffioen, D., Groen, A., \& Nak, J. (2019). The integration of research in the higher education curriculum: A systematic review. The Higher Education Journal of Learning and Teaching, 10(1), DOI: https://doi.org/10.24384/vhs6-1j85

Guerrero, S., Beal, M., Lamb, C., Sonderegger, D., \& Baumgartel, D. (2015). Flipping undergraduate finite mathematics: Findings and implications. PRIMUS, 25(9-10), 814-832. https://doi.org/10.1080/10511970.2015.1046003

Hew, K. F. \& Lo, C. K. (2018). Flipped classroom improves student learning in health professions education: A meta-analysis, BMC Medical Education, 18(1), 1-12, https://doi.org/10.1186/s12909-018-1144-z

Henningsen, B., Lohmann, N., \& Ørngreen, R. (2019). Stories from the north” Project: Digital storytelling in a youth and SoMe perspective. In Proceedings of the International Digital Storytelling, Conference Current Trends in Digital Storytelling: Research \& Practices, Zakynthos: UNESCO Club of Zakynthos, Greece (pp. 1-5)

Jensen, J. L.(2015), Improvements from a Flipped Classroom May Simply Be the Fruits of Active Learning. CBE Life Sci Educ., 14(1), ar5. doi: 10.1187/cbe.14-08-0129 Johnston, N. n.

Karkar, A. J. M., Fatlawi, H. K., \& Al-Jobouri, A. A. (2020). Highlighting E-learning Adoption Challenges using data Analysis Techniques: University of Kufa as a Case Study. The Electronic Journal of e-Learning, 18(2), 136-149, available online at www.ejel.org, DOI: 10.34190/EJEL.20.18.2.003

Kibuku, R. N., Ochieng, D. O., \& Wausi, A. N., (2020). e-Learning Challenges Faced by Universities in Kenya: A Literature Review. The Electronic Journal of e-Learning, 18(2), 150-161. DOI: 10.34190/EJEL.20.18.2.004 
Kite, J., Schlub, T. E., Zhang Y., Choi, S., Craske, S., \& Dickson, M. (2020), Exploring lecturer_and_student_perceptions_and_use_of_a_learning_management_system_in_a_postgraduate public_health_environment, E-Learning and Digital Media, https://doi.org/10.1177/2042753020909217.

Kolb, D. A. (1984). Experiental learning: experience as the source of learning and development, Chapter 2 "The process of experiential learning", [L’apprentissage expérientiel. L'expérience comme source d'apprentissage et de développement. Chapitre 2 « Le processus de l'apprentissage expérientiel »]. Récupéré sur le site de Faculté de médecine, Université Paris Est-Créteil (France)

Korableva, O., Durand, T., Kalimullina, O., \& Stepanova, I. (2019). Studying user satisfaction with the MOOC platform interfaces using the example of coursera and open education platforms. Paper presented at the ACM International Conference Proceeding Series, 26-30. https://doi.org/10.1145/3322134.3322139

Larsen, J. (2015). Adult students' experiences of a flipped mathematics classroom. Adults Learning Mathematics, 10(1), 50-67.

Lebrun, F. C. Kobelt G., Berg J., Capsa D., \& Gannedahl M. (2017). European Multiple Sclerosis Platform. New insights into the burden and costs of multiple sclerosis in Europe: Results for France. Mult Scler., 23(2_suppl), 65-77. doi: 10.1177/1352458517708125.

Lezer, V. A., Shabatura, L. N., \& Karnaukhov, I. A. (2020). The flagship University’s model in terms of digitalization: The case of industrial university of tyumen as a center of strategic decisions in the field of smart-city, IoT/IIoT and big data. Lecture Notes in Networks and Systems, 91, 387-396. DOI :https://doi.org/10.1007/978-3-030-32015-7_43

Lo, C. K., Hew, K. F., \& Chen, G. (2017). Toward a set of design principles for mathematics flipped classrooms: A synthesis of research in mathematics education, Educational

Research Review, 22, 50-73, https://doi.org/10.1016/j.edurev.2017.08.002

Love, B., Hodge, A., Corritore, C., \& Ernst, D. C. (2015). Inquiry-based learning and the flipped classroom model. PRIMUS, 25(8), 745-762.

https://doi.org/10.1080/10511970.2015.1046005

Engel, M., Heinz, M., \& Sonntag, R. (2017). Flexibilizing and Customizing Education using Inverted Classroom Model, Information Systems Management, https://doi.org/10.1080/10580530.2017.1366221

Moore, J. L., Dickson-Deane, C., \& Galyen, K. (2011). E-Learning, online learning, and distance learning environments: Are they the same? The Internet and Higher Education, 14(2), 129-135. DOI: 10.1016/j.iheduc.2010.10.001

Naccarato, E., \& Karakok, G. (2015). Expectations and implementations of the flipped classroom model in undergraduate mathemati Inverted Classroom Model", Information Systems Management, cs courses. International Journal of Mathematical Education in Science and Technology, 46(7), 968-978, https://doi.org/10.1080/0020739X.2015.1071440

Naseri, E. (2019). Comparing the impact of audio-visual input enhancement on collocation learning in traditional and mobile learning contexts. Applied Research on English Language, 8(3), 383-422.

O'Flaherty, J., Phillips, C., Karanicolas, S., Snelling, C., \& Winning, T. (2015). The use of flipped classrooms in higher education: A scoping review. The Internet and Higher

Education, 25, 85-95. https://doi.org/10.1016/j.iheduc.2015.02.002 
Puzanova, Z. V. and Larina, T. I. (2019). Social dimension of students' problems under the development of the contemporary university infrastructure. RUDN Journal of Sociology, 19(4), 800-813. DOI: http://dx.doi.org/10.22363/2313-2272-2019-19-4-800-813

Poleman, W., Jenks-Jay, N., \& Byrne, J. (2019). Nested networks: Transformational change in higher education. Sustainability (United States), 12(2), 97-99.

https://doi.org/10.1089/sus.2019.29152

Presti, C. R. (2016). The flipped learning approach in nursing education: A literature review. Journal of Nursing Education, 55(5), 252-257. DOI:10.3928/01484834-20160414-03

Radcliffe, D., Knappenberger, T., Daigh, A. L., \& David, M. (2016). Using Khan Academy Videos in Flipped Classroom Mode to Bolster Calculus Skills in SoilPhysics Courses.

Natural Sciences Education, 45. doi:10.4195/nse2016.04.0008

Rogers, J., \& Révész, A. (2020). Experimental and quasi-experimental designs. The Routledge handbook of research methods in applied linguistics. New York: Routledge.

Sweller, J., (1988). Cognitive load during problem solving: Effects on learning, Cognitive Science, 12, 257-285. https://doi.org/10.1207/s15516709cog1202_4

Sahin, M. \& Kurban, C. F. (2016). The Flipped Approach to Higher Education: Designing Universities for Today's Knowledge Economies and Societies. UK: Emerald. ISBN 978- 1786357441.

Seery, M. K. (2015). Flipped learning in higher education chemistry: Emerging trends and potential directions. Chemistry Education Research and Practice, 16(4), 758-768. https://doi.org/10.1039/C5RP00136F

Shaik, F. F., Makhecha, U. P., \& Gouda, S. K. (2020). Work and non-work identities in global virtual teams: Role of cultural intelligence in employee engagement. International Journal of Manpower, https://doi.org/10.1108/IJM-03-2019-0118

Salisbury, F., Hannon, J., \& Peasley, J. (2019). Framing the digitally capable university: Digital literacies as shared scholarly and professional practice. Paper presented at the ASCILITE 2017 - Conference Proceedings - 34th International Conference of Innovation, Practice and Research in the use of Educational Technologies in Tertiary Education, 152-157.

Scott, C. E., Green, L. E., Etheridge, D.L. (2016). A comparison between flipped and lecturebased instruction in the calculus classroom, Journal of Applied Research in Higher Education, 8(2), 252-264, https://doi.org/10.1108/JARHE-04-2015-0024

Sit, H. W., \& Guo, S. (2019). An exploration of design principles to enhance students' L2 acquisition in a flipped class. In Tso, A. W-b. (Ed.), Digital humanities and new ways of teaching (111-131). (Digital Culture and Humanities : Challenges and Developments in a Globalized Asia; Vol. 1). Hong Kong: Springer, Springer Nature.

https://doi.org/10.1007/978-981-13-1277-9_7

Strayer, J. F. (2012). How learning in an inverted classroom influences cooperation, innovation and task orientation, Learning Environments Research, 12(2), 171-193, https://doi.org/10.1007/s10984-012-9108-4

Tofade, T. et al. (2013). Best Practice Strategies for Effective Use of Questions as a Teaching Tool. DOI:10.5688/ajpe777155

Taurisson, A. \& Herviou, C. (2015). Activity pedagogy: for a new inverted class. Theory and practice of "work to learn". [Pédagogie de l'activité : pour une nouvelle classe inversée. Théorie et pratique du « travail d'apprendre »]. Issy-les-Moulineaux : ESF Editeur 
DOI: 10.14807/ijmp.v12i5.1401

Tractenberg, R. E., Lindvall, J. M., Attwood, T., \& Via, A. (2020). Guidelines for curriculum and course development in higher education and training.

http://doi.org/10.31235/osf.io/7qeht

West, J (2019). Using new literacies theory as a lens for analyzing technology-mediated literacy classrooms. E-Learning and Digital Media, 16, 151-173.

https://doi.org/10.1177/2042753019828355

www.moodle.org (accessed April 9, 2020).

Zhou, S., \& Zhang, T. (2017). Research on the Construction of Flipped ClassroomModel for English Teaching Based on SPOC. Revista de la Facultad de Ingeniería U.C.V., 32, 267273. https://doi.org/10.3991/ijet.v13i01.7513

Ziegelmeier, L. B., \& Topaz, C. M. (2015). Flipped calculus: A study of student performance and perceptions. PRIMUS, 25(9-10), 847-860. Doi : 10.1080/10511970.2015.1031305 